\title{
CASE STUDY OF CONFORMITY ASSESSMENT OF AUTOMATED PRODUCTION LINE
}

\section{PRAKTYCZNY PRZYKLAD OCENY ZGODNOŚCI ZAUTOMATYZOWANEGO SYTEMU WYTWARZANIA}

\author{
Marek Dźwiarek \\ Central Institute for Labour Protection - National Research Institute \\ 07-701 Warszawa ul. Czerniakowska 16 \\ e-mail: madzw@ciop.pl
}

\begin{abstract}
According to machinery directive 2006/42/WE, "assemblies of machinery which, in order to achieve the same end, are arranged and controlled so that they function as an integral whole" are considered as a machine. It means that before putting an automated production line into service the conformity assessment should be conducted. Different directives, e.g. machinery directive, low voltage directive, pressure equipment directive, etc may apply to the machines and devices forming an automated production. It is a duty of the main manufacturer to appoint the responsibility to particular manufactures of machines and devices. Using the automated production line for production of glass wool, built by the SAINTGOBAIN Construction Products Poland, as a study case the general rules for conformity assessment of such have been presented in the paper.
\end{abstract}

Keywords: safety of machinery, conformity assessment, automated production lines

Streszczenie: Dyrektywa maszynowa 2006/42/WE do maszyn zalicza także „zespót maszyn, które w celu osiagnięcia wspólnego efektu końcowego zostały zestawione i sa sterowane w taki sposób, aby działały jako zintegrowana catośc’." Oznacza to, że przed wprowadzeniem zautomatyzowanej linii produkcyjnej do użytkowania powinna być wykonana ocena zgodności. Maszyny i urzadzenia wchodzace w skład linii podlegać moga postanowieniom różnych dyrektyw, np. maszynowej, niskonapięciowej, ciśnieniowej itp. Obowiazkiem inwestora jest określenie zakresu odpowiedzialności poszczególnych uczestników inwestycji. $W$ referacie zademonstrowano, na przykładzie zautomatyzowanej linii do produkcji waty szklanej, zbudowanej w firmie SAINT-GOBAIN Construction Products Polska Sp. z o.o., sposób postępowania przy ocenie zgodności takiej linii.

Stowa kluczowe: bezpieczeństwo maszyn, ocena zgodności, zautomatyzowane linie produkcyjne 


\section{Introduction}

More and more advanced production systems have been constructed recently in Poland as a result of the industry reconstruction observed nowadays, commonly having the form of automated production lines. Usually, in such lines many different machines made by different manufactures, for which either the declaration of conformity or the declaration of incorporation of partly completed machinery should be provided, form the production system. The main manufacturer of the automated production line for one's own use is responsible for assembling all machines and devices made by particular manufacturers into the integral whole. Machines and devices the production line consists of may be covered by the scope of different directives e.g., Machinery Directive, Law-voltage Directive, Electromagnetic Compatibility Directive, Pressure Equipment Directive. The main manufacturer is also responsible for defining the scopes of responsibility for the safety issue assigned to each particular subcontractor:

- manufactures of particular machines,

- manufactures of "partly completed machines",

- subcontractors making installations,

- subcontractors making control systems,

- the main manufacturer, who constructs the whole system, i.e., the industrial production line.

The fact that the investor, being previously considered as the machine manufacturer (the position governed by the rules of Machinery Directive 2006/42/EC) should be then qualified as a machine user (the position governed by the rules of the 2009/104/EC directive) poses some additional problems. It can be clearly seen that the issue of sharing responsibility between particular participants of the undertaking can be very troublesome for the investor.

The same applies to the case of constructing the glass wool production line shown in Fig. 1, made by SAINT-GOBAIN Construction Products Poland.

\section{General description of the production line under consideration}

We aim at showing the approach we took when the conformity assessment process was conducted in which CIOP-PIB and SAINT GOBAIN cooperated. The production line, a general scheme of which is shown in Fig. 1 was subject to the assessment. The line comprises 13 groups of 
machines and devices. In view of the manufacturing functions performed, one can easily separate six distinct production units among those groups:

- furnace

- carpet curing

- carpet forming

- cold end

- belt conveyors

- process water conditioning.

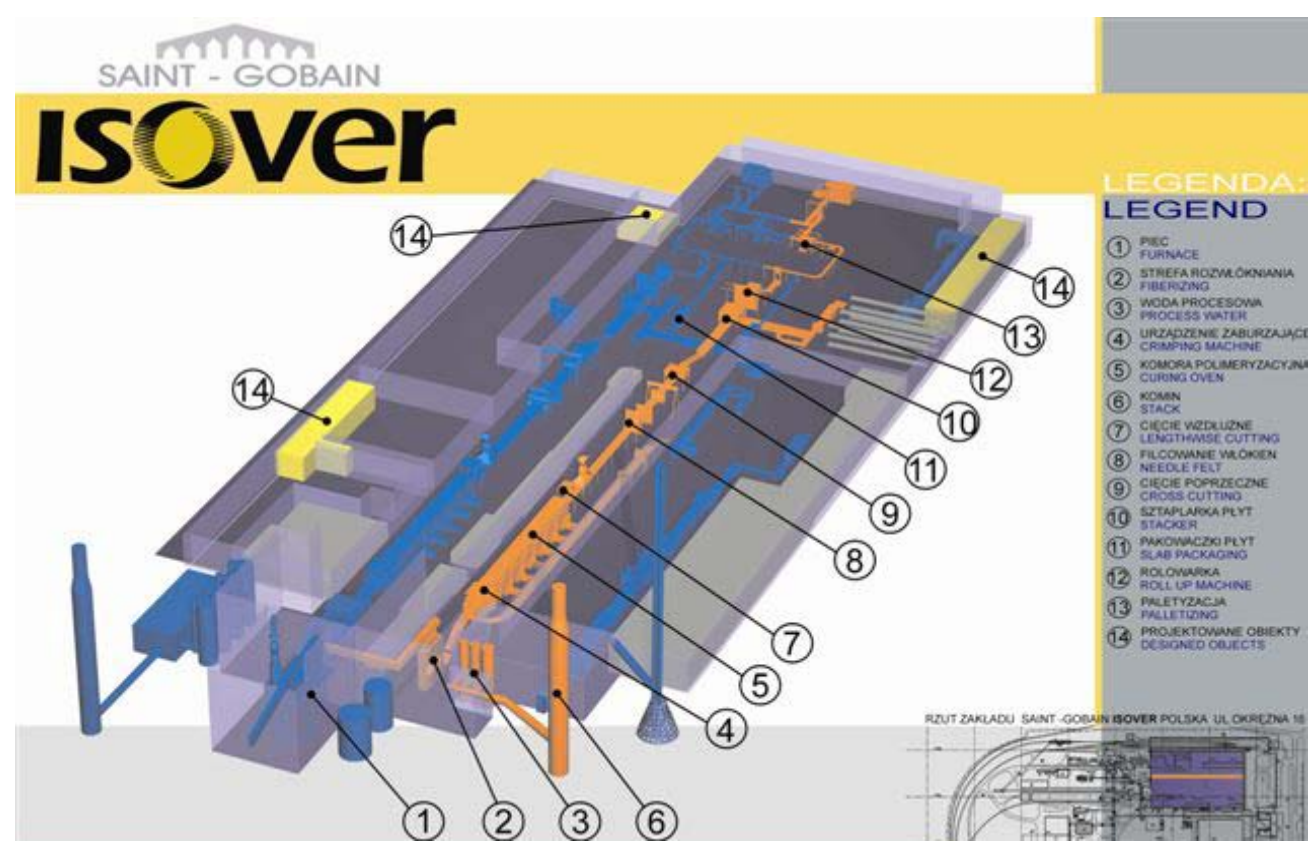

Fig. 1 General scheme of the glass wool production line

About a dozen different companies, established all over Europe, were engaged in the course of constructing the line. Besides the construction companies, they were mostly different machine manufacturers and integrators of automatic systems and installations. Therefore, the issue of defining the scope of responsibility for each manufacturer became of crucial importance. To this end, particular machines and devices should be extracted from the whole system and the rules governing them should be identified. The definition specified in the Machinery Directive should be considered as a point of reference. 


\section{The definition given by the Machinery Directive}

The production line was put into service in 2008, therefore the rules concerning basic requirements for machines and safety elements specified by directive $98 / 37 / \mathrm{WE}$ were applied to the conformity assessment. It is well-know that since December 30, 2009 the rules specified by directive 2006/42/WE have been applicable. Therefore, when analyzing investor's responsibility in manufacturing a production line which is to be put into service in 2010, one should employ the definitions given by directive 2006/42/WE.

According to directive 2006/42/WE the term machines includes:

a) an assembly, fitted with or intended to be fitted with a drive system other than directly applied human or animal effort, consisting of linked parts or components, at least one of which moves, and which are joined together for a specific application,

b) an assembly referred to in a), missing only the components to connect it on site or to sources of energy and motion,

c) an assembly referred to in a) and b), ready to be installed and able to function as it stands only if mounted on a means of transport, or installed in a building or a structure,

d) assemblies of machinery referred to in a), b) and c) or partly completed machinery which, in order to achieve the same end, are arranged and controlled so that they function as an integral whole.

Item e) concerns the lifting devices in which the only power source is a human effort applied directly, therefore it is not applicable in our case.

Before starting the conformity assessment procedure of automated production line the proper interpretation of those definitions was the issue of crucial importance. For Directive 98/37/WE the guide Community Legislation On Machinery, Comment on Directives 98/37/EC was very helpful. Now, the guide to Directive 2006/42/WE has been available.

The interpretation of definition given in item a) was the least troublesome. The definition encompasses all the purchased machines that were installed to form the production line. It should be noted here, that in the device considered as a machine at least one part should be moving, which excludes 
e.g., all installations, building structures, platforms, etc, from the scope of the Machinery Directive. The assessment of safety of those elements of the production line was conducted according to other rules.

A majority of the machines supplied have their own driving system. Nevertheless, there are often machines supplied which are to be connected to the driving system. According to item a) the devices of that type should also be considered as machines, and their suppliers are obliged to provide a detailed instruction on how to connect them with the driving system. On the other hand the Machinery Directive does not cover the devices driven by the human efforf. A handle-driven mixer may serve as an example of such devices.

That general principle does not cover the lifting devices, including all types of elevators and conveyors connected to the machines. In our case the recommendation specified in item b) implied that all the suppliers of machines which, for various reasons, were not provided with the elements allowing for their connection to energy sources and drives on the workplace, should supply also the instructions on how to establish such connections. Item c) is of crucial importance, since all the supplied devices were to be installed a building or a structure. When classifying the devices to be covered by that item the sentence "able to function as it stands only if mounted" played an essential role. In the case of automated production line it covers the devices; like, cranes, elevators, conveyors (especially the belt ones) as well as gates, doors and shutters, etc., supplied with their own drives. The suppliers of such machines were obliged to provide the conformity declaration with additional requirements for the buildings and structures on which the equipment is to be installed, especially in view of their mechanical strength.

However, most important was the issue of machine classification according to item d). Undoubtedly, the automated production line forms a group of machines operating in an integrated way. The requirement that the group should be controlled so that the machines function as an integral whole is essential in that case. This means that the machine group form a new machine when the following conditions are satisfied altogether:

- machines forming a group are put together to perform a common task, e.g. manufacture a specified product;

- machines forming a group are functionally connected in the way ensuring that operation of each machine affects the operation of other machines or the whole group; 
- machines forming a group share one control system or control systems of all machines are connected to form one, common system.

Therefore, the machines connected to perform a common function but operating independently of each other should not be considered as a machine. A series of machines sharing one conveyor may serve as an example here. All machines perform their own manufacturing operation one by one. Each machine is also connected with the conveyor control system in the way ensuring that the information on the performance of respective functions is transmitted e.g. to actuate the emergency stop of the whole production line. However, those machines do not share one control system operating therefore independently; despite the fact that their control systems inform each other about the performance stage of the functions. Thus, the requirements specified in item d) do not necessarily imply that the whole production line should be considered as a machine formed of a large number of machines and other equipment manufactured by different entities. However, in such systems the groups should be distinguished to be considered as one machine, for which sharing one control system is crucial. In that case the company making the integration should be considered as the manufacturer of a new machine, who should complete all formalities of the conformity assessment of the machine. However, manufacturers of the machines forming the group remain obliged to issue conformity declarations for manufactured machines since those machines, usually, can operate independently, (not necessarily forming a group with other machines). The only exceptions are the so-called "partly completed" machines, for which the manufacturer should provide the declaration of incorporation of the machine and the assembly instruction. It should be noted that the machines of that type in directive 98/37/WE bore the name "machines intended to be incorporated into machinery". A machine having the declaration "intended to be incorporated into machinery" was excluded from the scope of the directive and no additional actions of its manufacturer were needed, since all formalities of the conformity assessment were appointed to the manufacturer of a final machine. Since in our case the assessment was conducted according to directive $98 / 37 / \mathrm{WE}$, therefore the issue of partly completed machines was neglected. It is obvious, however, that the issue needs thorough analysis when performing the assessment according to directive 2006/42/WE. A key point here consists in the problem of automated production lines comprising both new machines and those being already in service. In our case the problem was neglected as not applicable, however it should be analyzed in details in future. 


\section{Responsibility assignment}

The investor who integrates a production line, in our case it was SAINTGOBAIN Construction Products Poland should ensure that the whole production line satisfies the requirements defined in the Machinery Directive. However the responsibility is shared also by suppliers of machines and equipment purchased to construct the line.

To this end one should first all classify the machinery into the following categories:

- purchased machines, which should be provided with the conformity declarations issued by their manufacturers;

- partly completed machines, which should be provided with the declaration "to be incorporated into machinery"( in the cases of newly constructed lines it would be the declaration of "partly completed machine", accompanied by the documents specified in directive 2006/42/WE)

- assemblies of machines controlled in the way ensuring that they work as an integrated system - manufacturers of particular machines issue the declarations for their machines, while SAINT-GOBAIN for the assembly

- installations and devices being elements of the constructed machines, for which the SAINT -GOBAIN demanded for the conformity declarations with the respective standards, necessary to issue the conformity declarations of machines,

- installations and devices not considered as machines, being therefore outside the scope of the Machinery Directive.

It should be done as early as possible in the course of investment procedure, making the negotiations of agreements with contractors much easier. Usually, however, it is impossible and the stage of initial concept of the investment. In our case the analysis was conducted when building work of the investment has started and a majority of contracts on manufacturing the machines were at their initial stages. At that stage of the investment assigning machines and devices to particular machine groups may pose some problems. The general concept of the production line was established basing on the issue of satisfying technological requirements not those imposed by the problem of conformity assessment. As a result of many discussions of experts from both the SAINT-GOBAIN and CIOP-PIB the conclusion was drawn and proved that problems which in general seem to be easy to solve in particular case usually occurred to be very difficult and 
needed thorough analysis. Finally, the attempt was made at using the virtual model of the production line under consideration.

Implementation of computer-aided techniques to the machine design process simplified considerably and speeded up the execution of the design tasks. Usually, computer simulations are applied to the analysis of functional properties of the designed devices, their technological capabilities and working parameters (Niewieczerzał, 2006). However, when designing a new machine a designer should consider also the issue of operator's safety. The presented research based on the assumption that the activities of the conformity assessment process may be pursued as early as at the machine design stage. Especially, the implementation of virtual reality systems into the design process may support strongly the designer when taking first steps in the risk assessment; as well as in the determination of the limits imposed on the machinery and hazard identification. Basic principles of implementation of virtual reality systems into safety-related applications have been known (Dźwiarek, 2008). However, to the best of Author's knowledge in the available literature on the subject there are not attempts at using a virtual model of automatic production line in the process of conformity assessment. Thus, in my opinion, the novelty of our approach to the issue of conformity assessment is worth noticing.

A virtual model of the designed production line developed at the pre-design stage, shown in Fig. 2 has been used in the analysis. The model represented accurately both the spatial proportions and machine arrangements. Despite the fact, that it did not contain detailed models of particular machines, it was accurate enough to be employed for identification and functional analysis of particular machines forming the production line. It allowed for a virtual "walk along" the production line, which enabled one to identify particular machine groups as well as follow the whole manufacturing process of glass wool, including indication of particular technological operations. Part of the model is shown in Fig. 2.

As a result of the analysis the production line was assumed to consist of:

- 26 machines not functioning as an integral whole, the conformity declarations of which are to be issued by their manufacturers;

- 1 machine having the declaration "partly completed machine"

- 8 machine assemblies arranged and controlled so that they function as an integral whole, the conformity declaration of which were issued by the SAINT-GOBAIN basing on the declarations issued by manufacturers of particular machines. 


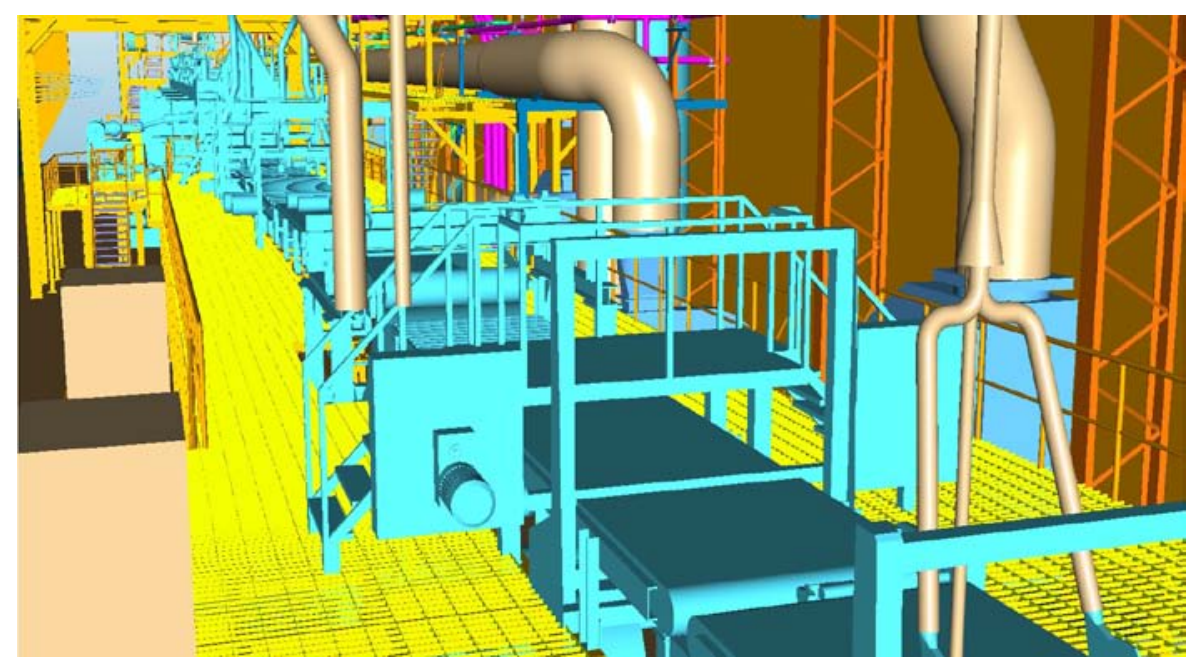

Fig.2 Part of the virtual model of automatic glass wool production line

The last group, among the other comprises also conveyors, for which a special attention was paid on the fact that their control systems communicated with the control systems of all cooperating machines. As a result of the signals coming from machines processing the carpet transported by the conveyor e.g., stopping of the conveyor unit might be actuated, or the drop zone might be opened in case of failure of one machine. However, that did not imply that all machines and conveyor units shared one control system. There was no need for considering them as a machine group specified in item d).

\section{Documentation on conformity assessment}

To prove that the production line may be put into service the main manufacturer should ensure the completeness of documentation proving that the essential safety requirements are satisfied for each particular machine the line comprises. Therefore, the documents were listed to be provided by the suppliers, depending on the device type. It was stated that the following documents should be provided by the suppliers of:

- machines:

- declaration of conformity with directives:

- 98/37/WE (machinery)

- 2006/95/WE (Low Voltage) 
- 2004/108/WE (EMC)

- others, as applicable,

- list of harmonized standards applied,

- instruction for the machinery,

- machine to be incorporated into machinery:

- declaration that the machine is intended to be incorporated into machinery,

- list of harmonized standards applied,

- description of the machine, including necessary actions to be taken to eliminate hazards imposed by the machine (if the assessment is performed according to directive 2006/42/WE, one should employ the requirements for partly completed machine)

- sub-assemblies:

- declaration of conformity with the respective directives

- normative references

- description of the subassembly including:

- principle of operation,

- range of applicability,

- parameters,

- the way of connecting it in the machinery,

- safety-related recommendations,

- forbidden applications.

- electrical equipment :

- declaration of conformity with directives:

- 98/37/WE (machinery)

- 2006/95/WE (Low Voltage)

- 2004/108/WE (EMC)

- list of normative references, including EN 60204-1,

- schematic and assembly diagrams,

- list of elements (cables, terminals, contactors, etc) together with their basic parameters,

- user guide, including frequency of necessary measurements of the protective circuit and checking elements of safety circuits, 
- reports containing the results of measurement of the protective circuit (insulation resistance tests, voltage test, continuity of the protective bonding circuit test, residual voltages test),

- manufacturers of control systems:

- declaration of conformity with directives:

-98/37/WE (machinery), within the scope of requirements imposed on the control system

- 2006/95/WE (Low Voltage)

- 2004/108/WE (EMC)

- list of normative references, including EN 62061 and EN 13849-1, or EN 954-1and EN 13849-2,

- schematic and assembly diagrams,

- list of elements together with their parameters, including MTTf for the safety function

- description of safety function together with the declarations of SIL or PL and category,

- user guide, including frequency of periodical checks and replacing necessity for safety-related elements.

It seems straightforward to collect the required documentation; however in practice; in the considered case a majority of the conformity declarations received did not satisfy the requirements imposed by the Machinery Directive. Most common nonconformities consisted in:

- the product, the declaration was issued for was identified in an inaccurate way,

- improper directive references (e.g., 89/392/EWG instead of 98/37/WE), not complete normative reference list (usually the lack of the directive on electromagnetic compatibility was found), even it was found that no directive was indicated, the conformity declaration was issued with,

- not updated normative references,

- there were no signatures of the persons responsible for issuing the declarations.

As a result, the process of conformity declaration collecting was elongated considerably, and even in an extreme case the manufacturer demanded a draft of conformity declaration to be provided. 
The problem of producing conformity documentation for groups of machines was much more complicated. Since the safety level during operation of a machine group depends not only on the design and technology of its elements but also on the way of connecting them, the machine groups were considered as covered by the scope of the Machinery Directive. Therefore, when performing risk assessment the manufacturer of a machine group should prove that each element, when taken separately, is properly chosen in view of safety as well as consider hazards imposed by integration of particular machines. He should also consider all the hazards posed by machine operation that were not included in the conformity declarations for particular machines issued by their manufacturers. For the aforementioned reasons it was necessary to produce the documentation of risk assessment that would indicate basic requirements for a given machine group specifying at the same time the ways of preventing from the identified hazards. To this end the check lists of basic requirements were produced, that included references to the documents proving that those requirements had been satisfied.

The software package PRO-M was used to support risk assessment in the machine design process (Dźwiarek, 2008). When filling check list the declarations of subsystem manufacturers were used, in which the harmonized standards employed were indicated. Those standards were then referred to in the final declaration of conformity. Thus the documentation of conformity assessment of a machine group contained check lists of essential safety requirements, reports on the measurement results (which was of crucial importance for electric installations) as well as conformity declarations issued by the manufacturers of machines and devices forming the group. Those who issue such declarations are obliged to store the documentation on the risk assessment for 10 years.

That applied especially to the manufacturers of control systems in view of satisfying the requirements specified in standards EN ISO 13849-1 and EN 62061.

\section{Putting into service}

After the line has been constructed it should be put into service. It means that the main machine producer who has been bound to the rules of Machinery Directive takes on now the role of its user who should confirm the rules of 2010/104/EC directive. The directive recommends initial 
inspection after installation and before putting it into service. The inspections were conducted as successive machines were purchased to be installed into the line. The results were documented in the form of check list of minimum safety requirements. That inspection allowed for identification of many nonconformities, appearing as a result of situating the machines relative to each other along the line. Most common irregularities consisted in:

- sizes of the machines access zones being not large enough,

- too small number of the emergency stop switches,

- lack of lighting signs that should be put on every element of the electric installation,

- no master power switches, cutting the machines off the power supply, especially in the cases of pneumatic and gas power supply,

- $\quad$ situating the master switches within the dangerous zones,

- application of inadequate guards.

As the machinery set comprising the production line was completed, the checks were made using the software package PRO-M (Dźwiarek, 2008), which allowed for identification of many non-conformities resulting from positioning of machines along the line, as well as from exceeding load limits for the human musculoskeletal system. Therefore some additional technical and organizational means should have been introduced. Those nonconformities were eliminated as they arose. As a result 34 check lists were produced according to minimum safety requirements.

\section{Conclusions}

The conformity assessment of the automatic glass wool production line conducted by the SAINT-GOBAIN in co-operation with the CIOP-PIB showed the problems a producer of such a line is confronted with when ensuring that the safety requirements and the formal ones, in view of the documentation of taken actions, have been satisfied. The main conclusion that can be drawn from the research conducted justifies that the conformity assessment issues should be considered as early as possible in the course of production line constructing. That can allow for early assignment of responsibility to the respective contractors and putting it into the agreements.

The approach, in which a virtual model of the line was used is of particular interest, since it proves that even simply virtual model not provided with 
constructional details may be very useful in the process of conformity assessment.

The problems one was confronted with when collecting the documentation from all subcontractors were typical for the undertaking of that kind. The issue of collecting conformity declarations for each device forming the line needs special attention both in view of their adequacy and logistic completeness. Not being careful enough and missing some issues may result in future in considerable obstacles one will be confronted with when gathering the documentation required by the market surveillance bodies. The activities pursued within that scope resulted in opening in SAINT GOBAIN Construction Product Poland a new archive department, where the documents were stored, previously distributed all over the company.

Construction of glass wool production line was a very complicated task in view of both technological and organizational issues. It needed a series of buildings and installations, together with their foundations, as well as connecting and putting into one production line several dozens of machines and devices supplied by various suppliers. Taking the aforementioned approach resulted in substantial improving of the undertaking performance efficiency. Both the conformity assessment and building and assembling work, including putting into service were performed simultaneously, to obtain the information on identified nonconformities as early as possible. The main producer was provided with the information necessary for correction steps to be taken as early as at the building stage of the line. Applying the aforementioned procedure to conducting the line construction process allowed for much more efficient work.

This paper has been prepared basing on the results obtained from a research task carried out within the scope of first stage of the National Programme "Improvement of safety and working conditions" partly supported in 2008-2010 - within the scope of research and developmentby the Ministry of Science and Higher Education. The Central Institute for Labour Protection - National Research Institute acts as the main coordinator of the Programme. 


\section{References}

1. Dźwiarek, M., Supporting tools for risk assessment during the machine design process. Journal of KONBIN, No. 3(6)/2008, str. 199-212, 2008

2. Dźwiarek, M., Application prospects of the augmented Reality Technology for improving Safety of Machine Operators. In: Human Computer Interaction. New Developments. Asai K. (ed.) In-Tech, Vienna, Austria, ISBN 978-953-7619-14-5, 217-230. 2008

3. Dźwiarek, M.,. Supporting tools for risk assessment during the machine design process. Journal of KONBIN, No. 3(6)/2008, str. 199-212. 2008

4. Niewieczerzał P. Virtual design of robotized production cells in: Virtual Designe and Automation, Weiss Z. (ed). ISBN 83-7143-228-3. 2006

5. Directive 98/37/EC Of The European Parliament and of The Council of of 22 June 1998 on on the approximation of the laws of the Member States relating to machinery. Official Journal of the European Union. L 207, P. 1 - 46, 23.07.98

6. Directive 2004/108/Ec of The European Parliament and of The Council of 15 December 2004 on the approximation of the laws of the Member States relating to electromagnetic compatibility and repealing Directive 89/336/EEC. Official Journal of the European Union. L 390/24 - 37, 31.12.2004

7. Directive 2006/42/EC Of The European Parliament and of The Council of 17 May 2006 on machinery, and amending Directive 95/16/EC (recast) Official Journal of the European Union, L 157/24 - 86, 9.6.2006

8. Directive 2006/95/EC of The European Parliament and of The Council of 12 December 2006 on the harmonisation of the laws of Member States relating to electrical equipment designed for use within certain voltage limits (codified version) Official Journal of the European Union, L 374/10 - 19, 27.12.2006

9. Directive 2009/104/EC of the European Parliament and of the Council of 16 September 2009 concerning the minimum safety and health requirements for the use of work equipment by workers at work (second individual Directive within the meaning of Article 16(1) of Directive $89 / 391 / E E C)$ Official Journal of the European Union. L 260/5 - 19, 3.10.2009

10. EN 954-1:1996 Safety of machinery - Safety-related parts of control systems - Part 1: General principles for design

11. EN ISO 13849-2:2003 Safety of machinery - Safety-related parts of control systems - Part 2: Validation 
12. EN ISO 13849-1:2006 Safety of machinery - Safety-related parts of control systems - Part 1: General principles for design

13. EN 60204-1/A1:2009 Safety of machinery - Electrical equipment of machines - Part 1: General requirements

14. EN 62061:2005 Safety of machinery - Safety-related parts of control systems - Part 1: General principles for design

15. Guide to application of the Machinery Directive 2006/42/EC. 1st Edition, European Commission, Enterprise and Industry. December 2009

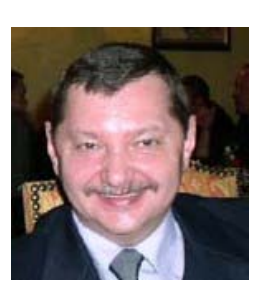

Marek Dźwiarek PhD. Eng. Central Institute for Labour Protection National Research Institute, Warsaw, Poland, head of Department of Safety Engineering, specialisation: safety systems for machinery, functional safety of machinery control systems, risk assessment, humanmachine interaction. He is author of several publications in field of safety of machinery. He is chair of PKN TC 281 "Safety of machinery. Electrotechnical aspects", IEC 44 and CENELEC 44X "Safety of machinery. Electrotechnical aspects", ISO TC 199/WG8 "Safety of machinery, Safety related control systems", Scientific Committee of International Conference of Safety of Industrial Automated Systems, Associate Editor of International Journal of Occupational Safety and Ergonomics. 